\title{
Muscle Protein Breakdown in Uncontrolled Diabetes as Assessed by Urinary 3-Methylhistidine Excretion
}

\author{
G. Marchesini ${ }^{1}$, G. Forlani ${ }^{2}$, M.Zoli ${ }^{1}$, P. Vannini ${ }^{2}$ and E.Pisi ${ }^{1}$ \\ ${ }^{1}$ Istituto di Patologia Speciale Medica 1, and ${ }^{2}$ Cattedra di Malattie del Ricambio, University of Bologna, Italy
}

\begin{abstract}
Summary. In an attempt to evaluate muscle protein catabolism in patients with uncontrolled diabetes, urinary excretion of 3-methylhistidine was measured in eight diabetic subjects, during poor control and after achievement of satisfactory control. The results were compared with the excretion values of ten healthy subjects fed a similar amount of meat. In the diabetic patients in poor metabolic control, 3-methylhistidine excretion was significantly increased compared with the healthy subjects, and returned to normal when a satisfactory glycaemic control was achieved. No significant differences were
\end{abstract}

observed between ketonuric and non-ketonuric uncontrolled patients. Improved glycaemic control reduced 3-methylhistidine excretion in both insulin-dependent and non-insulin-dependent diabetes. These results suggest increased protein catabolism causing muscle protein loss and negative nitrogen balance in diabetic patients with poorly controlled disease.

Key words: 3-Methylhistidine, diabetic control, muscle catabolism, protein degradation.
The regulatory action of insulin on protein metabolism is well known. In uncontrolled diabetes mellitus, absolute or relative insulin deficiency is associated with an increased nitrogen excretion and weight loss [1]. The relative importance of decreased protein synthesis $[2,3]$ and increased protein degradation [4] in the negative nitrogen balance remains controversial.

Previous studies [5] have shown that estimation of urinary 3-methylhistidine (3-MH) may be useful to assess the rate of muscle protein catabolism in subjects eating a meat-free diet or on a fixed meat intake [6]. This amino acid is present almost exclusively in myofibrillar protein and, after release on proteolysis, is not re-used for protein synthesis but is rapidly excreted in urine [5].

To evaluate the rate of muscle protein breakdown in uncontrolled diabetes, we examined 3-MH excretion in diabetic subjects both with poorly controlled disease and after achievement of satisfactory control. 3-MH excretion values, as well as other indices of metabolic control, were compared with data obtained in a group of healthy subjects fed a similar amount of meat.

\section{Materials and Methods}

\section{Patients}

The study was carried out in diabetic subjects attending our outpatient clinic. Subjects with severe uncontrolled diabetes (fasting blood glucose $>17 \mathrm{mmol} / 1$; urinary glucose $>800 \mathrm{mmol} /$ day) were interviewed by one of us (G.F.) regarding their food intake during the 3 days preceding analysis. Only subjects in whom a reliable history of meat intake could be obtained were eligible for the study. In eight patients worsening of diabetic control or onset of overt diabetes proved to be associated with an excess of carbohydrate or alcohol intake (>100 $\mathrm{g}$ of alcohol or $300 \mathrm{~g}$ of carbohydrate/day during the 10-15 days preceding analysis), while meat intake did not exceed $150 \mathrm{~g} /$ day. Seven males and one female (aged 35-55 years; median age: 51 years) were studied. Their mean height was $169 \pm 2 \mathrm{~cm}$ ( \pm SEM), and the mean weight was $70 \pm 3 \mathrm{~kg}$ ( \pm SEM). Four had Type 1 (insulin-dependent) diabetes of long-standing (5-15 years), while four had Type 2 (non-insulin-dependent) diabetes. The Type 1 patients were receiving a total amount of 32-56 Units of Lente insulin daily in single (two patients) or divided doses. None of them had evidence of hepatic or renal dysfunction. They were put on a strictly controlled dietary regimen, containing $26-30 \mathrm{Kcal} / \mathrm{kg}$ of body weight ( $45 \%$ of carbohydrates), and the meat intake was fixed at $150 \mathrm{~g} /$ day of lean beef. Insulin treatment was continued in the four Type 1 diabetic patients. The Type 2 diabetic subjects received glibenclamide $(15 \mathrm{mg} /$ day). Total 24-h urine specimens were collected into a dark bottle containing $2 \mathrm{ml}$ of $6 \mathrm{~N}$ hydrochloric acid as preservative, and brought to the clinic the following morning, when fasting venous blood samples for substrate and hormone determinations were drawn. At this time the patients still had poorly controlled diabetes (Table 1). Four patients (three Type 1 and one Type 2) had ketone bodies in the urine.

All the diabetic patients were followed during the next 4-26 days (mean 10 days) on an outpatient basis until satisfactory control was achieved (fasting blood glucose $<9 \mathrm{mmol} / 1$; urinary glucose $<80 \mathrm{mmol} /$ day) when fasting levels of substrates and hormones, as well as $3-\mathrm{MH}$ excretion values, were retested. During the whole study the patients did not change their every-day habits and physical activity was encouraged; no drugs were allowed apart from insulin and glibenclamide. 
Table 1. Fasting levels of substrates and hormones, and urinary excretion of creatinine, urea-nitrogen, and 3-methylhistidine (3-MH) in diabetic and control subjects

\begin{tabular}{|c|c|c|c|c|c|c|c|c|}
\hline & $\begin{array}{l}\text { Blood } \\
\text { glucose } \\
(\mathrm{mmol} / 1)\end{array}$ & $\begin{array}{l}\text { Urinary } \\
\text { glucose } \\
\text { (mmol/day) }\end{array}$ & $\begin{array}{l}\text { NEFA } \\
(\mathrm{mmol} / \mathrm{l})\end{array}$ & $\begin{array}{l}\text { Branched-chain } \\
\text { amino acids } \\
(\mu \mathrm{mol} / 1)\end{array}$ & $\begin{array}{l}\text { Glucagon } \\
(\mathrm{pmol} / \mathrm{l})\end{array}$ & $\begin{array}{l}\text { Urinary } \\
\text { creatinine } \\
\text { (mmol/day) }\end{array}$ & $\begin{array}{l}\text { Urinary } \\
\text { urea-N } \\
\text { (mmol/day) }\end{array}$ & $\begin{array}{l}\text { Urinary } \\
3-\mathrm{MH} \\
(\mu \mathrm{mol} / \text { day })\end{array}$ \\
\hline \multicolumn{9}{|l|}{$\begin{array}{l}\text { Diabetic subjects } \\
(n=8)\end{array}$} \\
\hline Poor control & $15.6 \pm 0.7^{\mathrm{a}}$ & $661 \pm 86$ & $0.81 \pm 0.07^{\mathrm{a}}$ & $700 \pm 64^{\mathrm{b}}$ & $58 \pm 9^{b}$ & $13.9 \pm 0.9$ & $517 \pm 73$ & $349 \pm 31^{a}$ \\
\hline Good control & $6.3 \pm 0.5^{c}$ & $(0-72)$ & $0.39 \pm 0.03^{\mathrm{c}}$ & $451 \pm 25^{d}$ & $44 \pm 5^{\mathrm{d}}$ & $11.6 \pm 0.9^{d}$ & $396 \pm 49^{d}$ & $258 \pm 32^{d}$ \\
\hline
\end{tabular}

Results are expressed as means \pm SEM. Branched-chain amino acid values are the sum of valine, isoleucine and leucine.

a $p<0.01 ;$ b $p<0.05$ : significantly different from control values.

${ }^{c} p<0.01 ;{ }^{d} p<0.05$ : significantly different from the corresponding value in poorly controlled patients

Ten healthy subjects (eight males and two females) with normal blood glucose and a normal oral glucose tolerance test served as controls. Their ages ranged from 28 to 58 years (mean 49 years); they had a mean height of $170 \pm 3 \mathrm{~cm}$ ( \pm SEM) and a mean weight of $68 \pm 2 \mathrm{~kg}$ ( \pm SEM). In these subjects all analyses were performed after a 3-day standard diet containing $150 \mathrm{~g}$ of meat/day, to balance previous possible differences of meat intake.

All subjects were within $10 \%$ of their ideal body weight (diabetic patients: $106 \pm 2 \%$, and control subjects: $104 \pm 2 \%$; mean \pm SEM).

All diabetic and control subjects gave their consent to take part in the study, after the nature and purposes of the research had been explained to obtain cooperation in urine collection and maintenance of the dietary regimen.

\section{Methods}

Venous blood samples were drawn from an antecubital vein after an overnight fast in both the diabetic and control subjects. The samples were tested for glucose, glucagon, non-esterified fatty acids (NEFA), and free amino acids by methods described previously [7]. The 24-h urine volumes were recorded and aliquots were immediately assayed for glucose, urea nitrogen and creatinine [8]. 3- $\mathrm{MH}$ was determined on aliquots, kept frozen at $-20^{\circ} \mathrm{C}$, by means of a 3A 28 Carlo Erba amino acid analyzer (Carlo Erba Strumentazione, Rodano, Italy) as described previously [9]. Urine was not hydrolysed before analysis because it has been shown that nearly all $3-\mathrm{MH}$ is excreted in man without being transformed into $\mathrm{N}$-acetyl-3-methylhistidine [10].

Statistical analysis between diabetic and control values was performed by means of the Mann-Whitney $\mathbf{U}$ test. Differences between values of diabetic patients during poorly controlled disease and after the achievement of a satisfactory control were tested for significance by means of Wilcoxon's signed rank test. Results are expressed as mean \pm SEM.

\section{Results}

In the poorly controlled patients, whose fasting blood glucose, NEFA, and branched-chain amino acids were significantly increased, and in the presence of a marked glycosuria (Table 1), 3-MH excretion was increased by nearly $50 \%$ compared with control subjects. No statistically significant differences were observed between the four ketonuric and the four non-ketonuric diabetic patients ( $366 \pm 31$ and $332 \pm 50 \mu \mathrm{mol} / \mathrm{day}$, respectively). In the same group of patients, no differences were present in fasting blood glucose $(16.8 \pm 0.5$ versus
$14.4 \pm 1.0 \mathrm{mmol} / \mathrm{l})$ or glycosuria $(712 \pm 137$ versus $611 \pm 117 \mathrm{mmol} /$ day). After achievement of a satisfactory control, fasting values of substrates returned to normal, as did 3-MH excretion (Table 1). In the Type 1 diabetic patients, 3-MH was reduced from $386 \pm 53$ to $231 \pm 35 \mu \mathrm{mol} /$ day $(p<0.01)$, while in the Type 2 patients less significant variations were observed ( $314 \pm 34$ versus $275 \pm 28 \mu \mathrm{mol} /$ day; $p<0.05$ ). The amelioration of metabolic control in the diabetic patients significantly reduced urinary excretion of urea-nitrogen and creatinine.

\section{Discussion}

Several methods have been used to assess muscle protein breakdown, but all are subject to remarkable drawbacks. The measurement of urinary 3-MH proved to be an easy, reproducible and reliable method to quantify the turnover of myofibrillar protein [5]. A few sources of non-skeletal muscle endogenous 3-MH have been identified, including skin and gastrointestinal tissue [11]. However, current evidence suggests that about 75\% of total urinary 3-MH derives from skeletal muscle breakdown $[12,13]$, emphasizing the usefulness of the measurement of 3-MH in the assessment of muscle protein turnover.

A major problem in the use of urinary 3-MH comes from the demonstration that ingestion of protein containing 3-MH (mainly meat), may alter 3-MH excretion in a dose-related manner. Marliss et al. [6] have shown that the dietary contribution of 3-MH must be carefully quantified to estimate the extent of muscle protein catabolism.

In the present study, we tried to determine the rate of muscle breakdown in diabetic patients with poorly controlled disease to clarify the role of increased protein catabolism in negative nitrogen balance and muscle loss. In selecting our patients, we included only subjects whose meat intake in the 3 days before analysis could be quantified. From that time on, patients ate a fixed amount of meat. The presence of 3-MH in the diet ac- 
counted for the higher 3-MH excretion we observed in the control subjects compared with the data reported previously in subjects on a meat-free diet $[9,14]$, and did not allow us to calculate the apparent myofibrillar protein catabolic rates $[5,14]$.

Despite these drawbacks, our study suggests that in poorly controlled diabetes, a remarkable increase in protein catabolism is present. This alteration is corrected by administration of insulin or oral hypoglycaemic agents, which also reduce blood levels of substrates to normal.

Very few data have been reported concerning 3-MH excretion in diabetes. In the spontaneously diabetic 'BB' Wistar rat, Nakhooda et al. [15] have demonstrated that onset of overt diabetes is associated with a striking rise in urea- $\mathrm{N}$ and ammonia- $\mathrm{N}$, as well as a striking increase (about twofold) in 3-MH excretion. In insulintreated diabetic rats, 3-MH excretion is within the normal range and promptly increases upon withdrawal of treatment. Different results were obtained in a recent study in Type 1 diabetic patients, in whom a 15\% reduction of insulin therapy failed to increase urinary $3-\mathrm{MH}$ significantly [16]. It is noteworthy that, in this study, diabetic patients on normal insulin treatment were not in satisfactory metabolic control (marked glycosuria was present), and 3-MH excretion was already significantly increased compared with healthy control subjects. The authors conclude that an increased protein catabolism takes place in diabetic subjects in the absence of ketoacidosis. In contrast to this, in our study healthy subjects and diabetic patients in good metabolic control had very similar 3-MH excretion values.

In agreement with previous studies in vitro [4], our data suggest that in uncontrolled diabetes there is increased protein degradation and muscle protein loss, possibly in association with a decreased protein synthetic rate [2,3]. Further studies in diabetic patients fed a meat-free diet are needed to rule out the possible effects of different alimentary 3-MH intake, and to calculate the rate of muscle protein catabolism.

\section{References}

1. Cahill JF Jr, Aoki TT, Marliss EB (1972) Insulin and muscle protein. In: Freinkel N, Steiner D (eds) Handbook of physiology: the endocrine pancreas. American Physiological Society, Washington, DC, pp 561-575

2. Pain VM, Garlick PJ (1974) Effect of streptozotocin diabetes and insulin treatment on the rate of protein synthesis in tissues of the rat in vivo. J Biol Chem 249: 4510-4514

3. Jefferson LS, Li JB, Rannels ST (1977) Regulation by insulin of amino acid release and protein turnover in the perfused rat hemicorpus. J Biol Chem 252: 1476-1483

4. Dice JF, Goldberg AL (1981) Intracellular protein degradation and its regulation by hormones and nutrients. In: Marliss EB, Girard JR, Assan R (eds) Diabetes mellitus: a pathophysiological approach to clinical practice. John Wiley, New York, pp 216-227

5. Young VR, Munro HN (1978) $\mathrm{N}^{\top}$-methylhistidine (3-methylhistidine) and muscle protein turnover: an overview. Fed Proc 37: 2291-2300

6. Marliss EB, Wei C-N, Dietrich LL (1979) The short-term effect of protein intake on 3-methylhistidine excretion. Am J Clin Nutr 32: 1617-1621

7. Vannini P, Marchesini G, Forlani G, Angiolini A, Ciavarella A, Zoli M, Pisi E (1982) Branched-chain amino acids and alanine as indices of the metabolic control in Type 1 (insulin-dependent) and Type 2 (non-insulin-dependent) diabetic patients. Diabetologia 22: 217-219

8. Edwards KDG, White HM (1958) The measurement of creatinine in plasma and urine. Aust J Exp Biol Med Sci 36: 383-394

9. Marchesini G, Zoli M, Angiolini A, Dondi C, Bianchi FB, Pisi E (1981) Muscle protein breakdown in liver cirrhosis and the role of altered carbohydrate metabolism. Hepatology 1: 294-299

10. Long CL, Haverberg LN, Young VR, Kinney JM, Munro HN, Geiger JW (1975) Metabolism of administered 3-methylhistidine in man. Metabolism 24: 929-935

11. Nishizawa N, Noguchi T, Hareyama S (1977) Fractional flux rates of $\mathrm{N}^{\tau}$-methylhistidine in skin and gastrointestine: the contribution of these tissues to urinary excretion of $\mathrm{N}^{\tau}$-methylhistidine in the rat. Br J Nutr 38: 149-151

12. Afting EG, Berhardt W, Janzen RWC, Rothig HJ (1981) Quantitative importance of non-skeletal muscle $\mathrm{N}^{\tau}$-methylhistidine and creatine in human urine. Biochem J 200: 449-452

13. Harris CI (1981) Reappraisal of the quantitative importance of nonskeletal muscle sources of $\mathrm{N}^{\tau}$-methylhistidine in urine. Biochem J 194: 1011-1014

14. Zoli M, Marchesini G, Dondi C, Bianchi GP, Pisi E (1982) Myofibrillar protein catabolic rates in cirrhotic patients with and without muscle wasting. Clin Sci 62: 683-686

15. Nakhooda AF, Wei C-N, Marliss EB (1980) Muscle protein catabolism in diabetes: 3 -methylhistidine excretion in the spontaneously diabetic 'BB' rat. Diabetes 29: 1272-1277

16. Huszar G, Koivisto V, Davis E, Felig P (1982) Urinary 3-methylhistidine excretion in juvenile onset diabetes: evidence of increased protein catabolism in the absence of ketoacidosis. Metabolism 31: 188-191

Received: 5 January 1982

and in revised form: 9 July 1982

Giulio Marchesini, M.D.

Istituto di Patologia Medica 1

Università di Bologna

Policlinico S Orsola

9, Via Massarenti

I-40138 Bologna, Italy 